\title{
PEMANFAATAN SPA (SISTEM PEMBERKASAN AGENDA) DI KELURAHAN RANGKUI MENGGUNAKAN METODE OMT (OBJECT MODELLING TECHNIQUE)
}

\author{
Sarwindah \\ Sistem Informasi, STMIK Atma Luhur, \\ indah_syifa@atmaluhur.ac.id
}

\begin{abstract}
Abstrak
Agenda suatu bentuk penyampaian berita, ide-ide atau pendapat yang disampaikan secara tertulis dari satu pihak kepada pihak lain, dari penyampaian tersebut terjadilah hubungan timbal balik sehingga terjadilah kegiatan surat menyurat terutama Laporan. Disini penulis bertujuan untuk mengetahui proses surat masuk dan surat keluar tersebut masih diproses manual dengan menggunakan menulis di buku besar. Oleh karena itu, penulis berinisiatif membuat perancangan sistem informasi pemberkasan agenda surat keluar dan masuk berdasarkan Disposisi. Sistem informasi Pemberkasan ini terdiri dari pendataan surat yang ada terutama surat masuk, surat keluar dan pembuatan laporan yang berhubungan dengan surat menyurat. Selain itu, sistem tersebut didukung dengan model UML untuk membantu analisa data dan diharapkan dapat mempermudah kelancaran proses pemberkasan sehingga menghasilkan informasi yang lebih akurat serta mendukung untuk peningkatan proses pemberkasan di kelurahan Rangkui kec.Kelapa dan metode yang digunakan adalah OMT(Object Modelling Technique).
\end{abstract}

Kata Kunci: Sistem, Pemberkasan Agenda, UML dan OMT

\section{PENDAHULUAN}

Pemberkasan Agenda yang terdiri dari surat menyurat sangatlah penting bagi perusahaan dan instansi pemerintah untuk menerima informasi dan memberikan informasi baik internal maupun eksternal, jika infomasi itu masuk kedalam perusahaan dan instansi, baik berupa lisan (ucapan pemberitahuan), lewat telepone, dan tulisan berupa memo atau surat, maka informasi yang masuk dan keluar tersebut hendak lah diketahui di disposisi kepada yang bersangkutan. Apabila informasi itu bersipat penting atau segera, maka pimpinan hurus bersifat memberi perintah tindak lanjutan mengikuti batas waktu sesuai isi informasi memo dan surat. Oleh karena itu membutuhkan informasi dalam melaksanakana tanggung jawab perencanaan, pengendalian dan penyajian, sehinggan semakin cepat tersaji, infomasi tentang Pemberkasan Agenda sura menyurat semakin baik terutama kelurahan Rangkui kec.Kelapa.Permasalahannya adalah, register dan penyusunan arsip masih manual (ditulis tangan dalam buku agenda) tanpa adanya softcopy/ back up data dan belum adanya sistem terkomputerisasi yang dapat membantu dengan lebih cepat dalam penangan berkas dari semua proses surat menyurat yang ada di kelurahan rangkui. Dimana agenda surat menyurat pada instansi kelurahan rangkui perlu mendapatkan perhatian dimana isi dari surat pada sebuah instansi akan menjadi sarana pencapaian tujuan dari instansi yang bersangkutan, maka dalam memperhatikan pemberkasan agenda perlu adanya pengurusan dan pengendalian atas surat. Hal itu harus diperhatikan supaya dalam Pelaporan berjalan lancar sesuai dengan tujuan yang diharapakn. adapun batasannya adalah: Surat Masuk, Surat Keluar, Disposisi dan Laporan Agenda Surat Masuk,Laporan Agenda Surat Keluar.Tujuan penulisan agar mempermudah pegawai dalam melakukan proses pendataan surat menyurat, sehingga proses tersebut terkontrol dengan baik, dapat dimanfaatkan sebagai bahan eferensi dasar untuk memperbaiki sistem pendataan surat menyurat yang 
sedang berjalan saat ini, dan mempermudah dalam pembuatan laporan Surat Masuk dan surat Keluar.

\section{TINJAUAN PUSTAKA}

A. Definisi Sistem

Suatu sistem pada dasarnya adalah sekelompok unsur yang erat hubungannya satu dengan yang lain, yang berfungsi bersama-sama untuk mencapai tujuan tertentu.

\section{B. Sistem Pemberkasan}

Sistem Pemberkasan adalah cara penyimpanan arsipsecara logis dan sistematis dengan memakai abjad, numerik/nomor, huruf ataukombinasi huruf dan nomor identitas arsip yang terkait(Amsyah 2003).Menurut Donni, Gamida dan Agus (2013) ada 5 macam sistem pengarsipan, yaitu :

\section{a) Sistem abjad}

Sistem abjad adalah sistem penyimpanan dokumen yang berdasarkan susunan abjad dari kata tangkap/nama dokumen bersangkutan.Melalui sistem abjad ini dokumen disimpan berdasarkan urutan abjad, kata demi kata, huruf demi huruf. Nama dapat terdiri dari dua jenis yaitu nama orang dan nama badan.

b) Sistem nomor

Sistem penyimpanan dokumen yang berdasarkan kode nomor sebagai pengganti dari nama-nama orang atau nama badan disebut sistem nomor.

c) Sistem geografis/wilayah

Sistem geografis berhubungan dengan letak tempat atau lokasi adalah suatu sistem penyimpanan arsip berdasarkan pembagian wilayah atau daerah yang menjadi alamat suatu surat.

d) Sistem tanggal (choronologis)

Sistem penyimpanan kronologi merupakan sistem penyimpanan yang didasarkan pada urutan waktu. Waktu disini dapat dijabarkan sebagai tanggal, bulan, tahun, dekade ataupun abjad. ${ }^{[7]}$.

\section{OMT (Object Modelling Technique)}

OMT adalah mengidentifikasi dan mengorganisasikan application-domain concept sampai pada implementation-domain concept. Metode Object Modelling Technique terdiri dari analisis, design dan implementasi.

\section{UML}

UMLadalah sekumpulan alat yang digunakan untuk melakukan abstraksi terhadap sebuah sistem atau perangkat lunak berbasis objek.
UML merupakan singkatan dari Unified Modeling Language. UML juga menjadi salah satu cara untuk mempermudah pengembangan aplikasi yang berkelanjutan, adapun Tools dari UML yang digunakan pada penelitian ini diantaranya:

a. Activity Diagram

menggambarkan proses bisnis dan urutan aktivitas dalam sebuah proses, yang mana dipakai pada business modelling untuk memperhatikan urutan aktifitas proses bisnis karena bermanfaat untuk membantu memahami proses secara keseluruhan dalam memodelkan sebuah proses.

a. Analisa Dokumen Keluaran

Analisa keluaran adalah bagian dari sistem yang fungsinya menjelaskan dokumen-dokumen apa saja yang dihasilkan sistem berjalan.Dokumen keluaran yang dihasilkan dari sistem berjalan dapat dianalisa dari activity diagram yangtelah dibuat. Caranya amati dokumen apa yang dibuat oleh bagian tempat sistem berlangsung dan diberikan kepada bagian/ swimlane lain.

\section{b. Analisa Dokumen Masukan}

Analisa masukan adalah dokumen yang berasal dari bagian lain dan diterima oleh bagian gudang. Caranya amati activity diagram, tentukan berada di swimlane yang mana sistem berada. Dokumen masukan adalah dokumen yang diterima gudang dari swimlane lain.

\section{c. Entity Relationship Diagram}

ERD adalah sebuah model data yang menggunakan beberapa notasi untuk menggambarkan data dalam hal entitas dan relasi yang digambarkan oleh data tersebut.

\section{METODE}

OMT (Object Modelling Technique ) adalah sebuah metode Object Oriented untuk membangun software lewat koleksi objek-objek yang didalamnya mengandung data dan behavior. Karakteristik dari OMT adalah menemukan hal mendasar dari Object Oriented berupa Identity, Classification (class dan Object), polymorphism, Inheritance. Esensi dari Object Oriented Development. OMT adalah mengidentifikasi dan mengorganisasikan applicationdomain concept sampai pada implementation-domain concept.Metode Object Modelling Technique terdiri dari analisis, design dan implementasi. 
Metode penelitian yang digunakan adalah :

a. Metode Analisa

Adapun tahapan-tahapan pada analisa sistem adalah sebagai berikut :

a) Activity Diagram

Activity diagram digunakan untuk memodelkan alur kerja sebuah proses bisnis dan urutan aktivitas dalam suatu proses.

b) Use Case Diagram

Use case diagram digunakan untuk menjelaskan manfaat sistem jika dilihat menurut pandangan orang yang berada di luar sistem.

\section{b. Desain Sistem}

Tahapan Desain sistem adalah merancang sistem secara rinci berdasarkan hasil analisa yang telah dilakukan, sehingga menghasilkan model sistem yang baru sesuai dengan yang telah diusulkan dengan disertai rancangan database dan spesifikasi program. Pada tahapan perancangan sistem, alat-alat yang digunakan adalah :

1) Entity Relationship Diagram (ERD)

ERD digunakan untuk menggambarkan hubungan antara entitas-entitas yang ada, bukan menggambarkan proses-proses yang terjadi.

2) Spesifikasi Basis Data

Spesifikasi basis data digunakan untuk menjelaskan tipe data yang ada pada model konseptual secara detil.

3) Sequence Diagram

Sequence diagram untuk menggambarkan interaksi antar objek di dalam dan di sekitar sistem (termasuk pengguna, display, dan sebagainya) berupa message yang digambarkan terhadap waktu.

\section{HASIL DAN PEMBAHASAN}

\section{A. Proses Bisnis}

1. Surat masuk dan Disposisi

Sekertaris menerima surat dari instansi dan mencatat surat masuk tersebut kedalam agenda surat masuk. Kemudian diserahkan pada Ka.Lurah untuk di disposisi. Setelah di disposisi Ka.Lurah menyerahkan kembali ke sekertaris lalu disimpan ke dalam agenda surat masuk sebagai arsip.

2. Surat Keluar

Sekertaris membuat surat keluar Kemudian mencatat surat keluar ke dalam agenda surat keluar dan diserahkan ke petugas pengiriman surat untuk diberikan kepada Instansi.

3. Laporan Agenda Surat Masuk dan Laporan Agenda Surat Keluar

Setiap bulan sekertaris akan membuat laporan agenda surat masuk kemudian diserahkan kepada Ka.Lurah lalu diarsipkan.

\section{B. Activity Diagram}

1. Activity Diagram Surat Masuk dan Disposisi

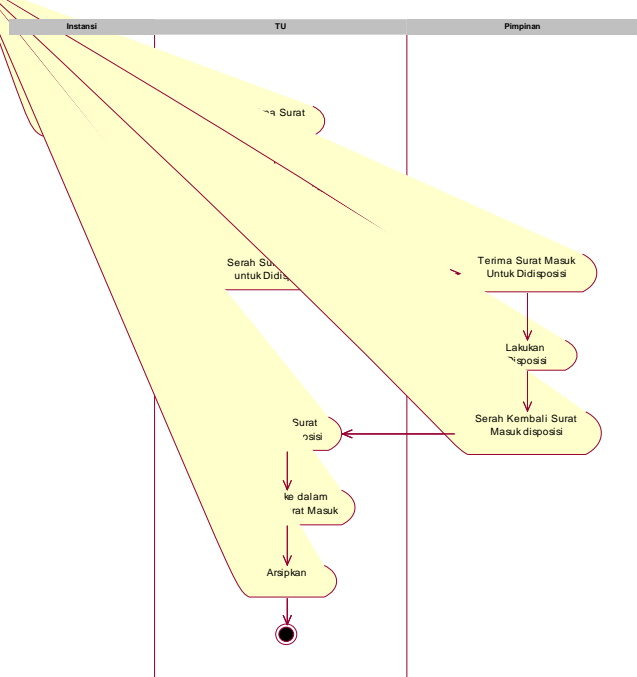

Gambar 1. Activity Diagram Suarat Masuk dan Disposisi

\section{Activty Diagram Surat Keluar}

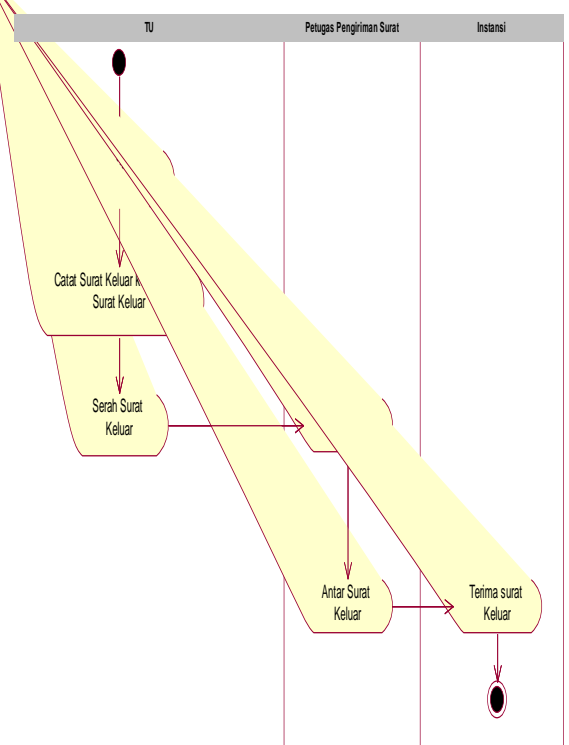

Gambar 2. Activity Diagram Surat Keluar 
ISSN 2477-0043

e-ISSN 2460-7908

3. Activty Diagram Laporan Agenda Surat Masuk

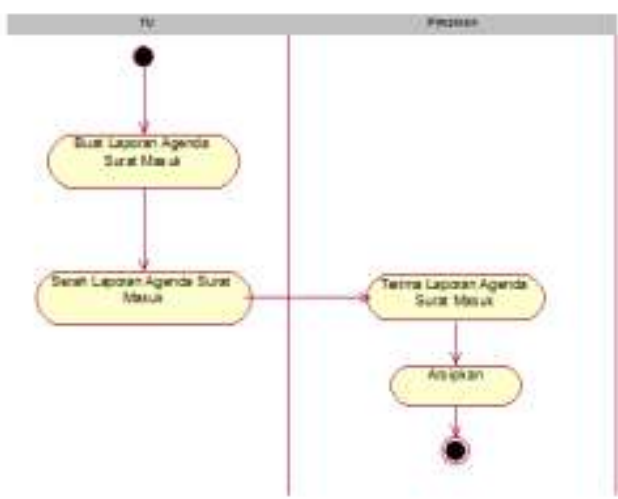

Gambar 3. Activty Diagram Laporan Agenda Surat Masuk

4. Activty Diagram Laporan Agenda Surat Keluar

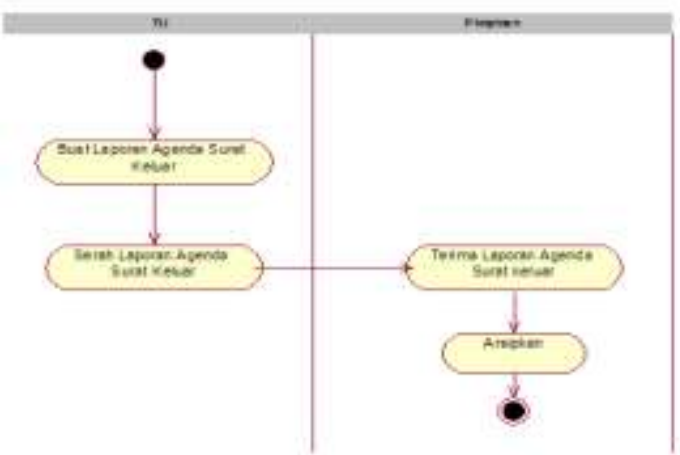

Gambar 4. Activty Diagram Laporan Agenda Surat Keluar

\section{Entity Relationship Diagram (ERD)}

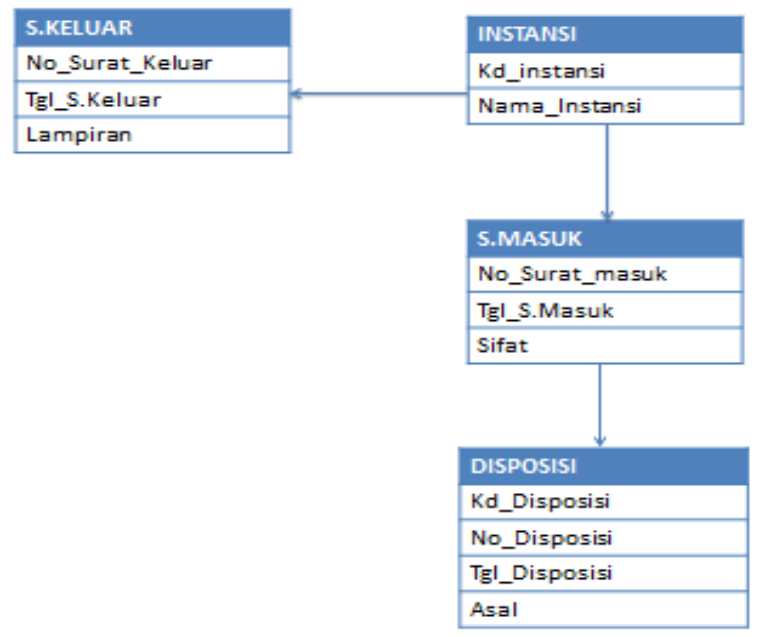

Gambar 5. ERD (Entity Relationship Diagram)
Jurnal Teknologi Terpadu

Vol. 5, No. 2, Desember 2019

D. Tampilan Rancangan Layar

1. Rancangan Layar Entry Data Instansi

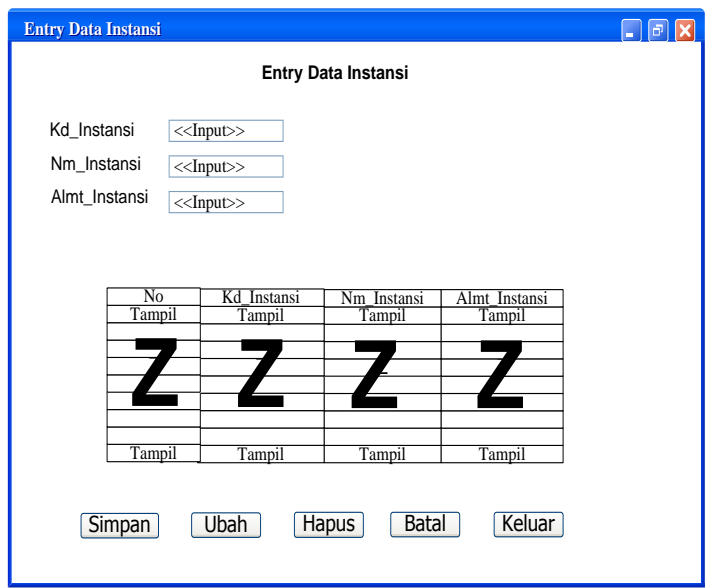

Gambar 6. Rancangan Layar Entry Data Instansi

2. Rancangan Layar Enty Surat Masuk

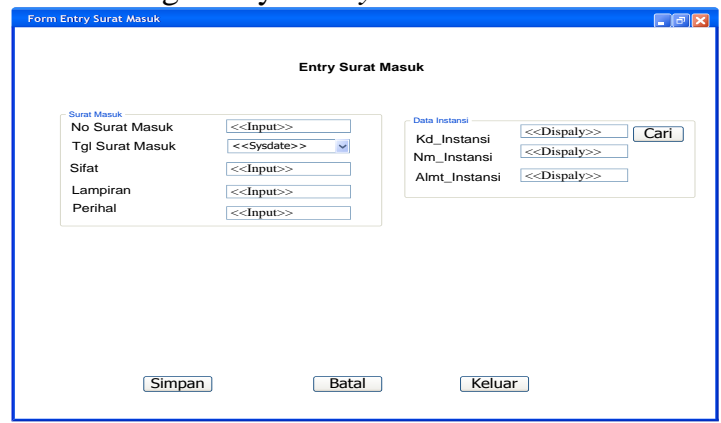

Gambar 7. Rancangan Layar Entry Surat Masuk

3. Rancangan Cetak Disposisi

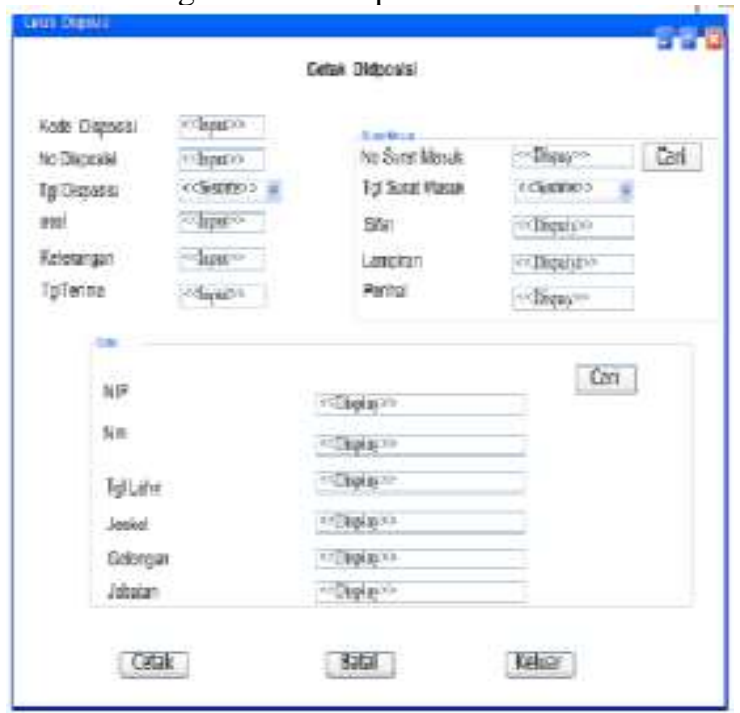

Gambar 8. Rancanagn Cetak Disposisi 
4. Rancangan Cetak Surat Keluar

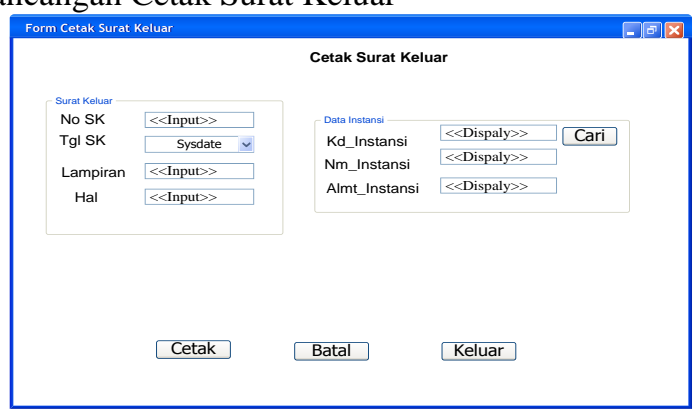

Gambar 9. Rancangan Layar Cetak surat Keluar

5. Hasil Cetak Disposisi

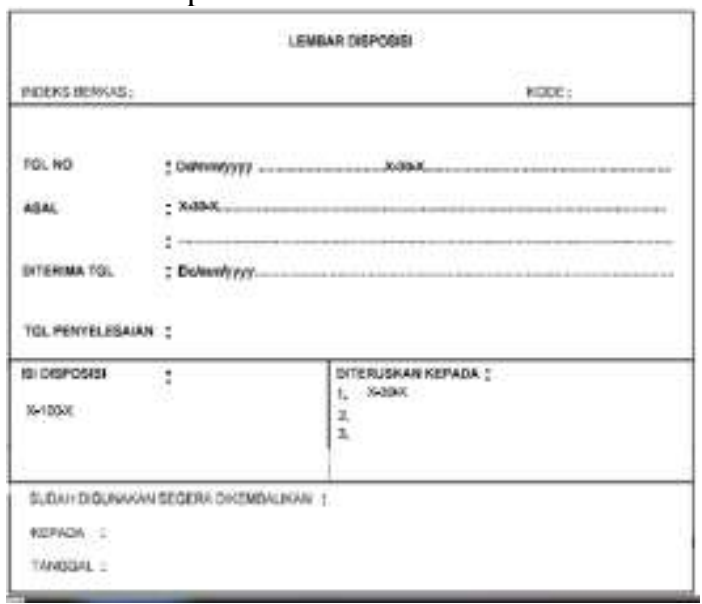

Gambar 10. Rancangan Cetak Disposisi

\section{KESIMPULAN}

Dalam Proses Pemberkasan Agenda surat menyurat yang sedang berjalan saat ini masih manual yaitu proses pencatatannya masih menggunakan buku besar atau buku agenda, pembuatan laporannya dilakukan dengan menggunakan microsoft word dan microsoft excel yang terpisah-pisah, sistem pendataan saat ini belum optimal, hal ini dikarenakan pada sistem yang sedang berjalan saat ini prosesnya belum menggunakan sistem terkomputerisasi sehingga datadata laporan surat masuk dan surat keluar tersebut proses pendataan surat yang dihasilkan belum berjalan dengan baik, dan Sistem pendataan surat menyurat yang berjalan saat ini perlu dirubah menjadi sistem informasi komputerisasi,
Untuk pengembangan sistem dan penelitian lebih lanjut diharapkan pendataan surat menyurat harus lebih rapi dan perlu arsipan dalam bentuk file khusus untuk penyimpannan data-data surat yang ada dan Melakukan backup atau dokumentasi secara periodik sebagai cadangan data yang ada dokumentasi dapat berupa laporan dalam bentuk cetakan kertas ataupun bentuk media lainnya.

\section{DAFTAR PUSTAKA}

[1] Sutabri, Tata. Analisis Sistem Informasi. Yogyakarta: Andi., 2012

[2] Heryanto, Imam. Membuat Database Dengan Microsof Access. Bandung: Informatika, 2009.

[3] Jogiyanto. Sistem Teknologi Informasi. Yogyakarta: Penerbit Andi, 2006.

[4] Komputer, Wahana. 2009. Panduan Praktis Microsoft Visio 2007. Yogyakarta: CV Andi Offset.

[5] Munawar. Pemodelan UML Berorientasi Objek. Jakarta: Andy Jogyakarta, 2007.

[6] Supardi, Yuniar. Semua Bisa Menjadi Program VB 6 Hingga VB 2008 Basic. Jakrta : Pt. Elek Media Komputindo, 2011.

[7] Taufiq, Rahmat. Sistem Informasi Manajemen. Edisi pertama. Yogyakarta: penerbit Graha Ilmu, 2013.

[8] Barsir Barthos, Manajemen Kearsipan: Untuk Lembaga Negara, Swasta, dan Perguruan Tinggi. Jakarta: Bumi Aksara, 2011 